\title{
Relative Factor Abundance and Relative Factor Price Equality in Punjab
}

\section{Resham Naveed ${ }^{*}$}

\begin{abstract}
This study tests the relative factor price equality across districts in Punjab using the methodology developed by Bernard, Redding, and Schott (2009) and data from the Census of Manufacturing Industries for 2000/01 and 2005/06. The results indicate the absence of relative factor price equalization due to the uneven distribution of factors in the province. Nonproduction (white-collar) workers) are relatively scarce in Punjab, which results in a wage premium for this type of labor. The study adjusts for worker quality by using a Mincerian wage equation as worker quality could explain the wage differential between white-collar and bluecollar workers. However, this exercise yields similar results, implying that factors are distributed unevenly across the districts of Punjab even after controlling for worker quality differences.
\end{abstract}

Keywords: Sector price, wages, equality, Punjab, Pakistan.

JEL classification: E24.

\section{Introduction}

Factor price equalization (FPE) is a central result of international trade theory. The Heckscher-Ohlin-Samuelson (HOS) theorem illustrates that trade in goods will lead to the equalization of factor prices across countries. In the absence of international trade, countries are bound to use the scarce factor in the production of goods and this receives a relatively high return. In international trade, however, countries will focus on goods that are intensive in the abundant factor and import goods that are intensive in the scarce factor; this results in the equalization of factor prices because the scarce factor is now available as an imported good.

Given that factors of production are embodied in goods, the movement of goods will lead to FPE. FPE is an important determinant of workers' receptiveness to international trade and patterns of labor mobility across regions. The geographic concentration of inputs then governs the

\footnotetext{
* Teaching Fellow, Lahore School of Economics.
} 
pattern of distribution of investments in terms of setting up industries across the world.

FPE is more likely to occur within a region or country because its two major determinants, factor mobility and goods mobility, are higher within a country than at a cross-country level. The question of FPE is also relevant at a regional level where it may determine government policies for national development plans. Moreover, variation in factor prices in a country leads to the movement of labor and industries to regions with higher incentives. Industry location is determined by factor prices because regions endowed with an abundant factor will have more industries that use that factor intensively.

Using the methodology developed by Bernard, Redding, and Schott (2009), this study investigates whether relative factor prices equalize across Punjab, Pakistan. Given that firm-level studies on Pakistan have received limited attention, this paper contributes to the literature by testing for relative factor price equality (RFPE) applied to a unique dataset. It would be interesting to see if the results of this analysis are in congruence with what the literature has already established. Pakistan is a developing country and it is inherently different from all the countries for which Bernard et al. (2009), among others, have tested for relative price equality.

The test is based on the "lens condition" developed by Deardorff (1994). The technique applied by Bernard et al. (2009) is used to check for the existence of factor lumpiness by testing to see if the relative wage bill for production to nonproduction workers equalizes across Punjab. Production or "blue-collar" workers are directly involved in producing goods, whereas nonproduction or "white-collar" workers are not involved directly in production.

RFPE is different from absolute factor price equalization (AFPE), for which the return on similar factors should equalize, for instance, the wages of nonproduction workers across regions. RFPE requires that relative factor prices should equalize rather than absolute factor prices, for instance, the relative wages of nonproduction to production workers across countries. RFPE allows us to control for interregional productivity differences because regions with higher productivity will pay more to both types of workers while the relative wage remains the same. 


\section{Literature Review}

The literature review examines the lens condition, tests for AFPE, and tests for RFPE.

\subsection{The Lens Condition}

Deardorff (1994) developed the lens condition to test FPE, using the concept of an integrated world economy (IWE) introduced by Dixit and Norman (1980). In an IWE, factors and goods across the world have perfect mobility and equilibrium is achieved under one set of equilibrium prices of goods and factors, techniques of production, and equilibrium quantities of goods demanded. Dixit and Norman argue that FPE is possible if, in the absence of factor mobility, it is possible to distribute factors in a country using certain techniques of production to replicate the outputs produced under the IWE. If this is not possible, then FPE is violated. Deardorff has formulated a visual representation of FPE, given below in Figure 1.

\section{Figure 1: FPE with two and three goods and two countries}

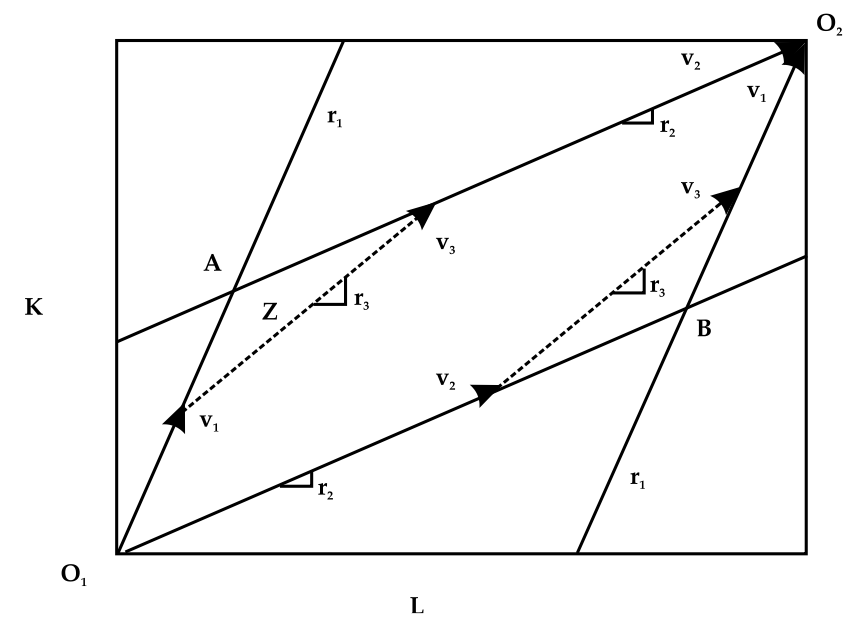

The axes $\mathrm{K}$ and $\mathrm{L}$ represent the world factor endowment for capital and labor, respectively. $\mathrm{O}_{1}$ is the origin for measuring factor endowment in country 1 and $\mathrm{O}_{2}$ is the origin for measuring factor endowment in country 2 . The lines originating from $\mathrm{O}_{2}$ and $\mathrm{O}_{1}$ have slopes equal to the ratio of both factors employed in industries. For FPE to occur, endowments must lie in the parallelogram $\mathrm{O}_{1} \mathrm{AO}_{2} \mathrm{~B}$. Let $x_{i}$ (where $i=1,2,3 \ldots$ ) be the quantity of goods produced under IWE. Vectors $v_{1}, v_{2}$, and $v_{3}$ represent the factors required to produce IWE quantities. These vectors outline the hexagonal area $\mathrm{O}_{1} v_{1} v_{3} \mathrm{O}_{2} v_{3} v_{2}$, which is the only portion of the box in which FPE can occur. 
The lens condition requires the variation in factor endowments across regions to be less than the variation in factor intensities across regions. To determine if the lens condition is met, the two-goods technique above can be modified for multiple goods. Factor endowments across regions are plotted first in decreasing order and then in increasing order of capital intensities. The two paths form a polyhedral lens, illustrated in Figure 2. The lens formed by plotting factor intensities is called a "country lens."

Following the same approach, factor use across sectors is plotted in decreasing and then increasing order of capital intensities. The resulting lens is the "goods lens." FPE is possible only when the country lens lies inside the goods lens. In other words, for FPE to hold, the factor endowment lens must be a subset of the factor use lens, and factor endowments across regions should vary less than factor intensities across goods.

Figure 2: Goods lens and country lens

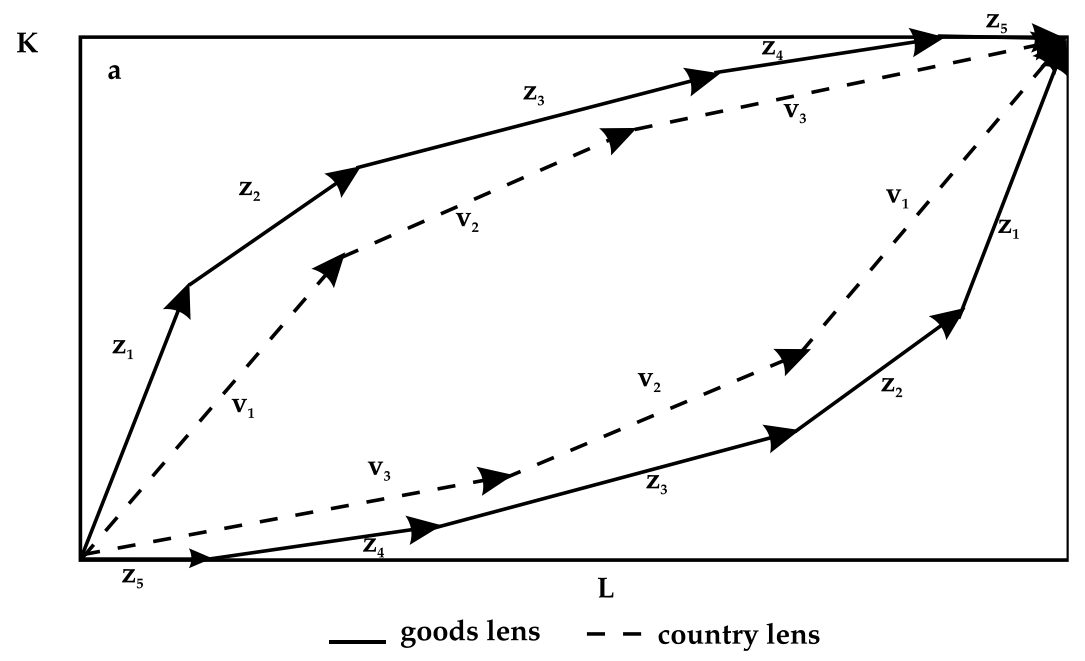

Cunat (2001) empirically tests for FPE across a sample of 114 countries by constructing a single-lens condition (which relates factor intensity in goods production to countries' factor endowments) for the entire world. He concludes that international trade cannot equalize FPE, but that FPE may be possible in certain regions. One concern regarding this methodology is that only two factor endowments (capital and labor) are analyzed when checking for FPE. In other words, there may be a multiplefactor case in which FPE holds. Debaere and Demiroglu (2003) examine the distribution of factor endowments using the lens condition throughout the world. Their results indicate that the condition is violated for the entire world as a whole, except for certain rich OECD countries. 
Under the HOS theorem, trade is determined by relative factor endowments and countries will export commodities that are rich in their abundant factors. Courant and Deardorff (1992) explain that regional factor endowments are also a driver of international trade. They show theoretically that an uneven regional factor distribution can result in international trade. For instance, in the case of a change in relative factor prices, a country with a lumpier distribution of factors can easily export the factor compared to a country with a relatively even distribution of that factor. If the factors of production are not distributed evenly in a country (lumpiness), then different regions within that country will specialize in the production of various goods. As a result, a lumpy country may have a larger mix of commodities that are produced and offer a variety of exports. This implies that not only international but also intra-national factor endowment differences can facilitate international trade.

Debaere (2004) checks for lumpiness in the UK, Japan, and India using the lens condition. The results show that the condition is not violated in all three countries and FPE holds in all three cases. This indicates that the empirical evidence does not support the argument concerning a lumpy distribution of factors of production in these countries.

\subsection{Absolute Factor Price Equality}

Tests for AFPE focus on the equalization of returns to similar factors across regions. Trefler (1993) reinforces the concept first presented by Leontief (also known as the Leontief-Trefler hypothesis) that FPE is possible when factors are adjusted for productivity differences, such as labor, which is known to exhibit significant cross-country productivity differentials. The results indicate that cross-country variations in factor prices are explained by the productivity differences in those factors. For instance, if wages in the UK are two thirds of the wages in the US, this would be because British workers are less productive than American workers by the same magnitude.

Davis and Weinstein (2001) empirically test the HOS theorem, based on the factor content of trade. Leontief (1953) found that US exports were relatively more labor-abundant than US imports. This contradicted the theory because the US was found to be labor-scarce at that time. Repetto and Ventura (1997) test the modified version of AFPE given by Trefler for a sample of all possible countries at different time intervals. ${ }^{1}$ The

${ }^{1} 1970,1975,1980$, and 1985. 
Leontief-Trefler hypothesis suggests that the difference in factor prices across countries is due to difference in the productivity of factors (see also Treffler, 1993). Their panel regression analysis indicates that the LeontiefTrefler hypothesis is not valid.

Burgman and Geppert (1993) suggest that the failure of AFPE may be because factor prices are nonstationary. Berger and Westermann (2001), however, argue that this result suffers from finite sample bias and that the data used for wages is nominal rather than real.

Studies based on cross-country analyses of AFPE and the lens condition indicate that factor prices do not equalize. There may be multiple regions in which AFPE holds, implying there may also be multiple cones of diversification (Cunat, 2001; Debaere \& Demiroglu, 2003). The evidence also suggests that factors inhibiting the free movement of trade might explain FPE failure, given that wages seem to be linked at a bilateral level (Burgman \& Geppert, 1993).

\subsection{Relative Factor Price Equality}

The problem inherent in testing for AFPE is that it does not account for productivity differences across regions, although it may be that the differential in factor prices between regions is due to such productivity differences. Testing for RFPE eliminates this problem: when the relative wage bill is calculated, the productivity difference between regions is canceled out. Thus, the focus of the literature has changed from testing AFPE to RFPE.

Given that unobserved differences in factor quality can cause problems when testing for FPE, Bernard et al. (2009) use a different methodology to control for these differences. Any given sector will employ different types of labor and their respective shares of employment will be determined by their relative wages. The authors test RFPE instead of FPE for 181 labor market regions across the US for 1972 and 1992. Relative price equalization means that relative factor prices should be identical for factor inputs. The methodology includes running a regression of the relative wage bill for nonproduction and production labor for two regions on a set of regional dummies. The significance of these dummies would indicate that RFPE was rejected. The test is done under the assumption of constant returns to scale and Hicks-neutral technology differences. 
The study's results indicate that the data do not exhibit RFPE and that there is a significant variation in real wages across regions; for some regions, the wage gap has increased over time. Additionally, the wide movement of all categories of labor across regions of the US indicates the integration of labor markets. Bernard et al. (2009) conclude that regional variations in factor endowments, the use of different production technologies in various regions, and increasing returns to scale might potentially explain why RFPE fails to hold.

Hanson and Slaughter (2002) obtain different results for AFPE in the US. Using a different methodology from Bernard et al. (2009), they test for the equalization of production techniques to determine if FPE holds. Their analysis indicates that AFPE does hold for the US, given the similarity of production techniques.

Bernard, Redding, Schott, and Simpson (2002) conduct a similar analysis testing for RFPE in the UK. They also report the absence of RFPE, finding that there is significant variation in real wages across the UK. Bernard, Robertson, and Schott (2010) use the lens condition to check for lumpiness in Mexico; they find that factors are unevenly distributed, as a result of which relative wages fail to equalize across Mexican regions.

Tomiura (2005) tests for AFPE and RFPE in Japan, following the methodology used by Bernard et al. (2009). The RFPE hypothesis is rejected for most regions in the country and the results are robust to differences in unobserved productivity. An additional test to determine the convergence of wages indicates that they have moved closer over the last decade, but the cross-region wage gap is still very high.

The literature on regional factor price convergence suggests that the distribution of factors even within countries is uneven and is one of the reasons that FPE fails at the regional level. This, in turn, implies that it may not be possible for factor prices to equalize at the international level. ${ }^{2}$ However, while the literature has shown that FPE can be violated, there is little explanation of the factors contributing to its failure. Most regional and cross-country studies reinforce the idea that FPE is not possible. The missing element is the extent to which the regional uneven distribution of factors contributes to factor price inequality

\footnotetext{
${ }^{2}$ This is in line with the results of the cross-country analysis.
} 


\section{Methodology and Estimation Strategy}

As far as relative wages and production structure are concerned, the empirical approach developed by Bernard et al. (2010) will be used to test for RFPE. This approach has significant advantages: it accounts for differences in unobserved factor quality and can be applied to economies with variations in prices and market structure.

Generating the wage bill allows us to control for unobserved factor quality. The relative wage bill in region $r$ is normalized by the relative wage bill in region $s$.

RFPE is tested using the following econometric specification:

$$
\operatorname{Ln}\left[\frac{R W_{r j}}{R W_{s j}}\right]=\sum_{r} \alpha_{r}^{s} d_{r}+\varepsilon_{\mathrm{rsj}}
$$

where $\mathrm{RW}=\mathrm{W}^{\mathrm{N}} / \mathrm{W}^{\mathrm{P}}, d_{r}$ is a set of regional dummies, and $\varepsilon_{r s j}$ is a stochastic term. If the set of regional dummies is jointly insignificant, then the null hypothesis of RFPE is not rejected.

First, we test for RFPE across the districts of Punjab by applying equation (1) to data on the wage bills for production and nonproduction workers taken from the Census of Manufacturing Industries (CMI) for 2000/01 and 2005/06.

Next, we ask whether differences in worker quality might drive the results obtained. Using a Mincerian wage regression, we adopt the methodology developed by Bernard et al. (2010), who argue that differences in the quality of workers may explain the variation in factor prices. It is very likely that workers are relatively more educated in one region, which enables them to earn a higher wage.

The objective is to establish a relationship between factor endowments and factor prices after removing the effects of worker quality. If factors are indeed lumpy, there should be an inverse relationship between relative wages and relative endowments across regions. In regions with a large endowment of a particular factor, the factor's price will be low. To ensure that differences in worker quality are not driving these results, we derive wage quantities of workers adjusted for observed quality, and test for this inverse relationship following Bernard et al. (2010). 
Mincer's (1958) human capital earnings function, where education is identified as a major determinant of a worker's wage growth, is estimated to correct for worker quality. The objective is to calculate the quality-adjusted relative wage and relative employment for every region. This is done by estimating the following model:

$$
\ln w_{i}=\alpha+\beta_{1} \text { education }+\beta_{2} \operatorname{sex}+\beta_{3} \text { age }+\varepsilon_{i}
$$

The equation above is a simple Mincerian equation where the wage of a worker is a function of his or her schooling, in order to incorporate the human capital effect. Better-educated workers will have more human capital and thus earn more. Age is an indicator of experience and will also positively affect wages, while sex captures the effect of gender on earnings. All three factors jointly determine the effect of worker quality on wages. $\alpha$ is a constant term that determines the wage independently of the effect of other explanatory variables, that is, the human capital effect (observed quality). ${ }^{3}$

Bernard et al. (2010) estimate a Mincerian wage regression separately for production and nonproduction workers, for each state and industry. Then, for each industry and state, the estimated constant term (a) for nonproduction workers is divided by the estimated constant term ( $a)$ for production workers. We estimate the Mincerian wage equation based on data from the Pakistan Social and Living Standards Measurement Survey (PSLMS) for 2008/09 for Punjab.

The ratio $\frac{\alpha_{i j}{ }^{N}}{\alpha_{i j}{ }^{P}}$ represents the relative wage bill (adjusted for observed quality) of nonproduction workers to production workers in state $i$ and industry $j$. To determine the employment level adjusted for observed quality, we calculate the following ratio for each occupation $h$, industry $j$, and state $i$ :

$$
\left(\frac{w^{\prime}}{\alpha}\right)_{h i j}
$$

The quantity of quality-adjusted nonproduction workers is calculated as the sum of this ratio across all states and industries for nonproduction workers. The same is done for production workers and the ratio of the two quality-adjusted quantities is then taken for each state and industry.

\footnotetext{
${ }^{3} \alpha$ represents the wage after the effect of human capital is removed.
} 
As mentioned above, an uneven distribution of factors will lead to a difference in factor prices, such that there is an inverse relationship between the relative quantity of a factor and relative factor price. This implies that the abundant factor will earn a lower return than the scarce factor. Using the quality-adjusted figures for wages and number of workers, the wage ratio is regressed on the ratio of nonproduction to production workers (controlling for industry-specific effects) to check for an inverse relationship between observed quality-adjusted wages and levels of employment.

$$
\frac{\alpha_{i j}{ }^{N}}{\alpha_{i j}{ }^{P}}=\alpha+\beta\left(\frac{w^{\prime}}{\alpha}\right)_{h i j}+\sum_{j} \gamma_{j} d_{j}+\varepsilon
$$

where $d_{j}$ refers to a set of industry dummies and $\varepsilon$ is an error term.

\section{Data}

Administered by the Pakistan Bureau of Statistics in collaboration with the provincial bureaus of statistics, the CMI provides basic data on manufacturing firms in Pakistan in terms of employment and wages, assets, stocks, output value, industrial taxes, production costs, and the value of raw and intermediate inputs. It covers manufacturing establishments registered under the Factories Act 1934, and includes all sectors of manufacturing from food processing to steel industries. The CMI for 2005/06 covers over 3,500 manufacturing firms while the CMI for 2000/01 covers about 2,300 manufacturing firms. We use data from the CMI to construct a relative wage bill for production to nonproduction workers in various regions.

Data from the Pakistan Social and Living Standards Measurement Survey (PSLMS) for 2008/09 are used to estimate the worker qualityadjusted model. The PSLMS is a household survey conducted by the Pakistan Bureau of Statistics that provides a set of district-level, population-based estimates of social indicators. Covering approximately 75,188 households, the survey includes indicators for education, health, water supply and sanitation, and households' economic situation.

There is a strong possibility that our analysis of these two datasets will yield different results, which will need to be carefully compared. The main difference is their coverage: the CMI is restricted to Punjab whereas the PSLMS covers all of Pakistan. Although restricting the PSLMS analysis to Punjab would help resolve the problem, the unit of analysis remains different: the CMI is a firm-level dataset and the PSLMS is a household-level dataset. 
It could also be argued that the results of both analyses will be different because the wages estimated from the two datasets cannot be directly compared, given the different units of analysis. However, the equations being estimated are also different from each other. Equation (1) tests for FPE using industry- and district-specific wages whereas districtlevel wages are used in the worker quality model. Even if the unit of analysis is different, the occupations are the same and the wages are estimated at an individual level to ensure that the difference in wages remains largely similar.

Table 1 gives the distribution of employment and industries across districts. The number of industries has increased over time, but the employment share of each district remains more or less consistent. In the absence of any drastic changes in the district data, there should not be much variation in the results obtained from the CMI 2000/01 and 2005/06.

There are some data limitations to consider. The response rate for the $\mathrm{CMI}$ is low, so it is possible that many production labor-intensive firms are not being accounted for. The response rate for the 2000/01 census was around 60 percent while that for 2005/06 was around 49 percent. 
Table 1: Distribution of employment and industries, by district

\begin{tabular}{|c|c|c|c|c|}
\hline \multirow[b]{2}{*}{ District } & \multicolumn{2}{|c|}{$\begin{array}{c}\text { Share of manufacturing } \\
\text { employment }\end{array}$} & \multicolumn{2}{|c|}{$\begin{array}{l}\text { Number of industries } \\
\text { in each district }\end{array}$} \\
\hline & 2000/01 & $2005 / 06$ & $2000 / 01$ & $2005 / 06$ \\
\hline Attock & 0.027 & 0.010 & 8 & 7 \\
\hline Bahawalnagar & 0.010 & 0.010 & 6 & 5 \\
\hline Bahawalpur & 0.014 & 0.010 & 13 & 8 \\
\hline Bhakkar & 0.017 & 0.016 & 2 & 7 \\
\hline Chakwal & 0.029 & 0.007 & 4 & 6 \\
\hline Dera Ghazi Khan & 0.021 & 0.008 & 7 & 6 \\
\hline Faisalabad & 0.100 & 0.059 & 36 & 32 \\
\hline Gujranwala & 0.040 & 0.037 & 64 & 59 \\
\hline Gujrat & 0.048 & 0.042 & 12 & 19 \\
\hline Hafizabad & 0.031 & 0.045 & 6 & 9 \\
\hline Jhang & 0.031 & 0.009 & 19 & 6 \\
\hline Jhelum & 0.021 & 0.019 & 10 & 6 \\
\hline Kasur & 0.056 & 0.108 & 27 & 29 \\
\hline Khanewal & 0.019 & 0.058 & 11 & 12 \\
\hline Khushab & 0.036 & 0.042 & 7 & 12 \\
\hline Lahore & 0.136 & 0.107 & 112 & 86 \\
\hline Layyah & 0.004 & 0.008 & 3 & 3 \\
\hline Lodhran & 0.001 & 0.000 & 4 & 17 \\
\hline Mandi Bahauddin & 0.014 & 0.013 & 3 & 5 \\
\hline Mianwali & 0.017 & 0.014 & 4 & 5 \\
\hline Multan & 0.047 & 0.021 & 34 & 25 \\
\hline Muzaffargarh & 0.044 & 0.064 & 6 & 10 \\
\hline Nankana Sahib & - & 0.017 & - & 7 \\
\hline Narowal & 0.001 & 0.001 & 2 & 3 \\
\hline Okara & 0.012 & 0.015 & 13 & 14 \\
\hline Pakpattan & 0.006 & 0.005 & 4 & 4 \\
\hline Rahimyar Khan & 0.033 & 0.022 & 10 & 9 \\
\hline Rajanpur & 0.000 & 0.006 & 1 & 3 \\
\hline Rawalpindi & 0.036 & 0.068 & 30 & 18 \\
\hline Sahiwal & 0.011 & 0.010 & 17 & 5 \\
\hline Sargodha & 0.015 & 0.013 & 14 & 14 \\
\hline Sheikhupura & 0.092 & 0.075 & 67 & 49 \\
\hline Sialkot & 0.010 & 0.009 & 23 & 26 \\
\hline Toba Tek Singh & 0.015 & 0.019 & 10 & 11 \\
\hline Vehari & 0.005 & 0.033 & 3 & 3 \\
\hline
\end{tabular}

Source: Author's calculations. 
The definition of nonproduction and production workers may also be problematic. The CMI includes some occupation, such as cleaning staff, in the nonproduction worker category, even though they do not qualify as white-collar workers. This could affect the results because the relative wage of nonproduction to production workers will be distorted downward by nonproduction workers who are not white-collar workers.

\section{Empirical Results}

It is important to mention at the outset that the base region $s$ is identified as all of Punjab. The CMI clearly differentiates between production and nonproduction workers, and gives information on the number of both types of workers and their wages. The wage bill for every firm is calculated by simply multiplying the number of workers and their respective wages (see Section 3). For the base region's relative wage in an industry, the wage bill for one type of worker is calculated by summing all the wage bills for that type of worker in that industry for Punjab overall.

The ratio of relative wage bills is calculated by dividing the summed wage bills for both types of workers in that industry for Punjab. It is important to note that this is industry-specific. For instance, if we calculate the relative wage bill for industry 1 and district 1 , the numerator will simply be the relative wage bill for firms in industry 1 in district 1 , but the base will be the ratio of the summed wage bills for industry 1 for the whole of Punjab (except district 1). In the final calculation of the relative wage bill, every observation is subtracted from the base to remove its individual effect, that is, the relative wage bill for district 1 and industry 1 is subtracted from the final relative wage bill for industry 1 in Punjab.

\subsection{Regression Results for RFPE}

Following the methodology developed by Bernard et al. (2009) for RFPE, the relative wage bill is regressed on a set of district dummies to check for the presence of RFPE (Table 2). 
Table 2: Regression results for RFPE

\begin{tabular}{|c|c|c|}
\hline \multirow[b]{2}{*}{ Variable (district) } & $2000 / 01$ & $2005 / 06$ \\
\hline & $\operatorname{Ln}\left[\frac{R W_{r j}}{R W_{s j}}\right]$ & $\operatorname{Ln}\left[\frac{R W_{r j}}{R W_{s j}}\right]$ \\
\hline \multirow[t]{2}{*}{ Attock } & $1.214^{*}$ & 0.723 \\
\hline & 0.674 & 1.070 \\
\hline \multirow[t]{2}{*}{ Bahawalnagar } & 0.989 & 0.548 \\
\hline & 0.870 & 1.070 \\
\hline \multirow[t]{2}{*}{ Bahawalpur } & 0.639 & -0.033 \\
\hline & 0.569 & 0.757 \\
\hline \multirow[t]{2}{*}{ Bhakkar } & -0.184 & 0.503 \\
\hline & 1.506 & 0.677 \\
\hline \multirow[t]{2}{*}{ Chakwal } & 1.102 & 0.600 \\
\hline & 1.506 & 0.874 \\
\hline \multirow[t]{2}{*}{ Dera Ghazi Khan } & $2.529^{* * *}$ & 0.581 \\
\hline & 0.870 & 1.070 \\
\hline \multirow[t]{2}{*}{ Faisalabad } & $0.910^{* *}$ & $0.913^{* *}$ \\
\hline & 0.389 & 0.404 \\
\hline \multirow[t]{2}{*}{ Gujranwala } & 0.331 & $0.518^{*}$ \\
\hline & 0.346 & 0.281 \\
\hline \multirow[t]{2}{*}{ Gujrat } & $1.094^{*}$ & $0.750^{*}$ \\
\hline & 0.615 & 0.437 \\
\hline \multirow[t]{2}{*}{ Hafizabad } & 0.344 & 0.162 \\
\hline & 0.870 & 0.757 \\
\hline \multirow[t]{2}{*}{ Jhang } & -0.490 & 0.185 \\
\hline & 0.533 & 0.677 \\
\hline \multirow[t]{2}{*}{ Jhelum } & -0.670 & 1.266 \\
\hline & 0.569 & 0.757 \\
\hline \multirow[t]{2}{*}{ Kasur } & $0.634^{*}$ & 0.590 \\
\hline & 0.389 & 0.378 \\
\hline \multirow[t]{2}{*}{ Khanewal } & 0.404 & 0.427 \\
\hline & 0.674 & 0.535 \\
\hline \multirow[t]{2}{*}{ Khushab } & 0.222 & -0.377 \\
\hline & 0.753 & 0.677 \\
\hline \multirow[t]{2}{*}{ Lahore } & $0.874^{* * *}$ & $0.918^{* * *}$ \\
\hline & 0.225 & 0.242 \\
\hline \multirow[t]{2}{*}{ Layyah } & 0.976 & - \\
\hline & 1.065 & \\
\hline \multirow[t]{2}{*}{ Lodhran } & -0.720 & 0.893 \\
\hline & 1.065 & 1.070 \\
\hline
\end{tabular}




\begin{tabular}{|c|c|c|}
\hline \multirow[b]{2}{*}{ Variable (district) } & $2000 / 01$ & $2005 / 06$ \\
\hline & $\operatorname{Ln}\left[\frac{R W_{r j}}{R W_{s j}}\right]$ & $\operatorname{Ln}\left[\frac{R W_{r j}}{R W_{s j}}\right]$ \\
\hline \multirow[t]{2}{*}{ Mandi Bahauddin } & 0.063 & 0.579 \\
\hline & 1.065 & 0.757 \\
\hline \multirow[t]{2}{*}{ Mianwali } & 0.171 & 0.616 \\
\hline & 0.870 & 0.757 \\
\hline \multirow[t]{2}{*}{ Multan } & 0.089 & 0.598 \\
\hline & 0.377 & 0.404 \\
\hline \multirow[t]{2}{*}{ Muzaffargarh } & -0.309 & 0.385 \\
\hline & 0.870 & 0.618 \\
\hline \multirow[t]{2}{*}{ Nankana Sahib } & - & 0.988 \\
\hline & & 0.677 \\
\hline \multirow[t]{2}{*}{ Narowal } & - & $-2.445^{*}$ \\
\hline & & 1.513 \\
\hline \multirow[t]{2}{*}{ Okara } & 0.518 & -0.418 \\
\hline & 0.533 & 0.535 \\
\hline \multirow[t]{2}{*}{ Pakpattan } & 0.231 & 1.153 \\
\hline & 1.065 & 1.070 \\
\hline \multirow[t]{2}{*}{ Rahimyar Khan } & 0.874 & 0.800 \\
\hline & 0.674 & 0.757 \\
\hline \multirow[t]{2}{*}{ Rajanpur } & 1.143 & $-5.016^{* * *}$ \\
\hline & 1.506 & 1.513 \\
\hline \multirow[t]{2}{*}{ Rawalpindi } & 0.474 & $0.900^{*}$ \\
\hline & 0.377 & 0.504 \\
\hline \multirow[t]{2}{*}{ Sahiwal } & 0.668 & -0.406 \\
\hline & 0.476 & 0.437 \\
\hline \multirow[t]{2}{*}{ Sargodha } & $0.896^{*}$ & $0.828^{*}$ \\
\hline & 0.476 & 0.504 \\
\hline \multirow[t]{2}{*}{ Sheikhupura } & $0.699^{* * *}$ & $0.695^{* *}$ \\
\hline & 0.266 & 0.291 \\
\hline \multirow[t]{2}{*}{ Sialkot } & 0.566 & -0.119 \\
\hline & 0.476 & 0.391 \\
\hline \multirow[t]{2}{*}{ Toba Tek Singh } & 0.618 & -0.696 \\
\hline & 0.569 & 0.618 \\
\hline \multirow[t]{2}{*}{ Vehari } & - & 0.639 \\
\hline & & 0.874 \\
\hline Observations & 276 & 286 \\
\hline R-squared & 0.2139 & 0.2147 \\
\hline Joint $\mathrm{P}$-value & 0.0011 & 0.0012 \\
\hline
\end{tabular}

Source: Author's calculations. 
The first important result is that all the district dummies are jointly significant for both years. This implies that we can reject the null hypothesis of full RFPE, that is, factor price inequality exists in Punjab for both years. However, the individual coefficients provide a somewhat different picture: relatively few districts have statistically significant coefficients. The individual coefficients represent how the relative wage in a district for an industry is different from the average relative wage in Punjab for the same industry. The wage is converted to logarithmic form to smooth out variations.

Second, most districts have a positive coefficient, which implies that the wage bill for a nonproduction worker in the district is greater than the wage bill for a nonproduction worker in the base region. Thus, a coefficient of 1.094 for Gujrat can be interpreted to mean that the relative wage in Gujrat is significantly 109.4 percent higher than the relative wage in Punjab overall.

Under the HOS theorem, a premium is offered to whichever type of labor is relatively scarce: if a region has abundant nonproduction labor, the latter will be offered lower wages. The excess supply of production labor in Pakistan leads to higher wages for nonproduction labor in most districts. For 2000/01, Sheikhupura and Lahore are the two districts that are significant at the 5 percent level. For Lahore, the wage bill for nonproduction workers is significantly 87 percent higher than that for nonproduction workers in the rest of Punjab; for Sheikhupura, the relative wage bill is significantly 69 percent higher than for the base region.

Table 3 gives the ratio of nonproduction to production workers for each district in the CMI 2000/01 and 2005/06. Table 4 shows the percentage distribution of labor in industries intensive in white-collar (nonproduction) workers and those intensive in blue-collar (production) workers. Both tables show the district-wise distribution of the endowments of both factors of production. 
Table 3: Ratio of nonproduction to production workers, by district

\begin{tabular}{|c|c|c|}
\hline District & $2000 / 01$ & $2005 / 06$ \\
\hline Attock & 0.238 & 0.439 \\
\hline Bahawalnagar & 0.406 & 0.346 \\
\hline Bahawalpur & 0.460 & 0.105 \\
\hline Bhakkar & 0.377 & 0.299 \\
\hline Chakwal & 0.074 & 0.529 \\
\hline Dera Ghazi Khan & 0.589 & 0.113 \\
\hline Faisalabad & 0.239 & 0.399 \\
\hline Gujranwala & 0.341 & 0.386 \\
\hline Gujrat & 0.119 & 0.170 \\
\hline Hafizabad & 0.389 & 0.356 \\
\hline Jhang & 0.219 & 0.483 \\
\hline Jhelum & 0.121 & 0.282 \\
\hline Kasur & 0.296 & 0.211 \\
\hline Khanewal & 0.237 & 0.435 \\
\hline Khushab & 0.270 & 0.306 \\
\hline Lahore & 0.285 & 0.271 \\
\hline Layyah & 1.449 & 0.422 \\
\hline Lodhran & 0.292 & 0.537 \\
\hline Mandi Bahauddin & 0.222 & 0.087 \\
\hline Mianwali & 0.274 & 0.433 \\
\hline Multan & 0.188 & 0.162 \\
\hline Muzaffargarh & 0.127 & 0.109 \\
\hline Nankana Sahib & - & 0.205 \\
\hline Narowal & 1.054 & 1.104 \\
\hline Okara & 0.519 & 0.310 \\
\hline Pakpattan & 0.500 & 0.342 \\
\hline Rahimyar Khan & 0.504 & 0.441 \\
\hline Rajanpur & 0.400 & 0.476 \\
\hline Rawalpindi & 0.232 & 0.232 \\
\hline Sahiwal & 0.252 & 0.076 \\
\hline Sargodha & 0.295 & 0.495 \\
\hline Sheikhupura & 0.240 & 0.271 \\
\hline Sialkot & 0.464 & 0.148 \\
\hline Toba Tek Singh & 0.418 & 0.721 \\
\hline Vehari & 0.394 & 0.100 \\
\hline
\end{tabular}

Source: Author's calculations 
Table 4: Distribution of manufacturing employment across industries

\begin{tabular}{|c|c|c|c|c|}
\hline \multirow[b]{3}{*}{ District } & \multicolumn{2}{|c|}{$2000 / 01$} & \multicolumn{2}{|c|}{$2005 / 06$} \\
\hline & \multicolumn{4}{|c|}{$\%$ of manufacturing employment in... } \\
\hline & $\begin{array}{c}\text { Production } \\
\text { labor- } \\
\text { intensive } \\
\text { industries }\end{array}$ & $\begin{array}{c}\text { Nonprod. } \\
\text { labor- } \\
\text { intensive } \\
\text { industries }\end{array}$ & $\begin{array}{c}\text { Production } \\
\text { labor- } \\
\text { intensive } \\
\text { industries }\end{array}$ & $\begin{array}{c}\text { Nonprod. } \\
\text { labor- } \\
\text { intensive } \\
\text { industries } \\
\end{array}$ \\
\hline Attock & 82.99 & 17.01 & 73.24 & 26.76 \\
\hline Bahawalnagar & 38.35 & 61.65 & 100.00 & 0.00 \\
\hline Bahawalpur & 17.40 & 82.60 & 29.62 & 70.38 \\
\hline Bhakkar & 56.10 & 43.90 & 56.45 & 43.55 \\
\hline Chakwal & 100.00 & 0.00 & 99.13 & 0.87 \\
\hline Dera Ghazi Khan & 95.32 & 4.68 & 91.05 & 8.95 \\
\hline Faisalabad & 91.86 & 8.14 & 93.92 & 6.08 \\
\hline Gujranwala & 77.40 & 22.60 & 78.62 & 21.38 \\
\hline Gujrat & 99.47 & 0.53 & 97.31 & 2.69 \\
\hline Hafizabad & 80.55 & 19.45 & 93.68 & 6.32 \\
\hline Jhang & 57.73 & 42.27 & 36.94 & 63.06 \\
\hline Jhelum & 96.19 & 3.81 & 95.35 & 4.65 \\
\hline Kasur & 96.01 & 3.99 & 94.66 & 5.34 \\
\hline Khanewal & 68.96 & 31.04 & 85.58 & 14.42 \\
\hline Khushab & 84.60 & 15.40 & 87.39 & 12.61 \\
\hline Lahore & 86.79 & 13.21 & 85.33 & 14.67 \\
\hline Layyah & 0.00 & 100.00 & 0.00 & 100.00 \\
\hline Lodhran & 27.31 & 72.69 & 3.05 & 96.95 \\
\hline Mandi Bahauddin & 45.97 & 54.03 & 32.90 & 67.10 \\
\hline Mianwali & 40.40 & 59.60 & 45.35 & 54.65 \\
\hline Multan & 69.29 & 30.71 & 83.12 & 16.88 \\
\hline Muzaffargarh & 95.65 & 4.35 & 91.84 & 8.16 \\
\hline Nankana Sahib & - & - & 68.88 & 31.12 \\
\hline Narowal & 0.00 & 100.00 & 0.00 & 100.00 \\
\hline Okara & 29.16 & 70.84 & 61.05 & 38.95 \\
\hline Pakpattan & 1.87 & 98.13 & 0.33 & 99.67 \\
\hline Rahimyar Khan & 30.65 & 69.35 & 8.42 & 91.58 \\
\hline Rajanpur & 100.00 & 0.00 & 0.00 & 100.00 \\
\hline Rawalpindi & 97.87 & 2.13 & 95.42 & 4.58 \\
\hline Sahiwal & 93.98 & 6.02 & 76.05 & 23.95 \\
\hline Sargodha & 54.58 & 45.42 & 53.80 & 46.20 \\
\hline Sheikhupura & 93.57 & 6.43 & 88.96 & 11.04 \\
\hline Sialkot & 97.55 & 2.45 & 99.66 & 0.34 \\
\hline Toba Tek Singh & 39.31 & 60.69 & 29.77 & 70.23 \\
\hline Vehari & 55.81 & 44.19 & 90.65 & 9.35 \\
\hline
\end{tabular}

Source: Author's calculations. 
A closer look shows that Sheikhupura and Lahore rank highest in terms of the number of industries present in 2000/01, i.e., 67 and 112 industries, respectively (Table 3). They also account for among the highest shares of manufacturing employment. For 2000/01, 94 percent and 87 percent of the total manufacturing labor is production labor employed in Sheikhupura and Lahore, respectively (Table 4).

Figure 3 and Table 3 show the distribution of the use of both types of workers as the ratio of nonproduction to production workers in each district. This ratio is 0.28 and 0.24 for Lahore and Sheikhupura, respectively (Table 3). This result reflects the HOS theorem: given the relative abundance of production labor in Lahore and Sheikhupura, their wage bill for nonproduction workers is relatively high.

Figure 3: Ratio of nonproduction to production workers, by district

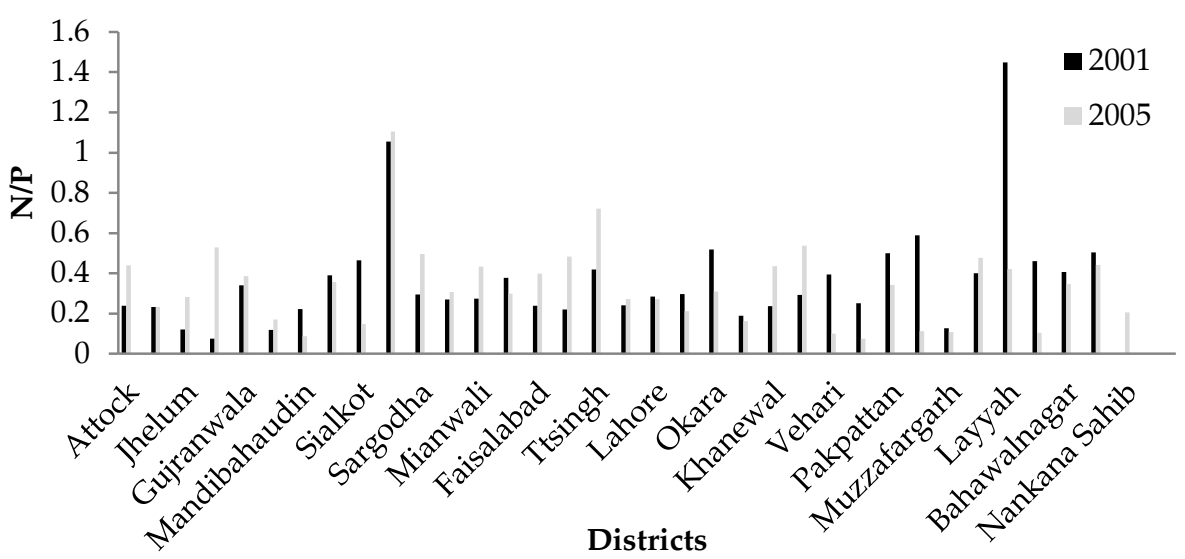

A similar picture emerges for Faisalabad, which is significant at the 5 percent level for 2000/01. According to the estimated coefficient, the relative wage bill for nonproduction workers is 91 percent greater than the relative wage bill for nonproduction workers in the rest of Punjab (Table 2). Again, around 92 percent of the manufacturing labor in this district is employed in production labor-intensive industries, implying that Faisalabad is heavily endowed with production labor, which leads to a higher wage for nonproduction workers in Faisalabad. The ratio of nonproduction to production workers is 0.23 (Table 3), which also indicates an abundance of production workers.

It is important to mention here that all the significant districts represent a larger number of observations. This has a positive impact on the result and the denominator is different in this case. When the district in the 
numerator has many observations, the denominator will be based on far fewer observations since the district in the numerator is excluded from the "base" relative wage in the denominator. The "base" relative wage is, therefore, less representative. As it turns out, it also falls significantly in these cases, likely because there are fewer nonproductive workers in the remaining districts used to calculate the "base" relative wage.

Gujrat, Kasur, Attock, and Sargodha are significant at the 10 percent level and have positive coefficients (Table 2). ${ }^{4}$ In Gujrat, 99 and 97 percent of labor is employed in production labor-intensive industries, respectively, for both years (Table 4), implying an abundance of production labor. The sign of the coefficient is in line with the HOS theorem.

Similarly, Sargodha has around 55 percent of its labor employed in production labor-intensive industries for both years, which is in line with the HOS theorem. The ratio of nonproduction to production workers is less than 0.5, confirming this. The sign is justified in the case of Attock where 83 percent of manufacturing employment is concentrated in production labor-intensive industries. In Kasur, 96 percent of manufacturing employment is in production labor-intensive industries and the ratio of nonproduction to production workers is less than 0.3 , confirming the significant positive sign (Table 4).

An important observation from the analysis is that almost all the significant districts in Table 2 belong to the industrial hub of central Punjab. They also account for the highest share of manufacturing employment and the highest number of industries located there. One exception is, however, Dera Ghazi Khan, which is significant at all levels with a positive sign. This is in line with the theory as it is heavily endowed with production labor. The coefficient of the district is very high and is greater than 1 for 2000/01 (Table 2).

However, this coefficient is based on only six industries operating there, which may be responsible for the large value. Most industries in Dera Ghazi Khan produce cement and related products such as lime, basic agricultural equipment, and cotton and related products.

Our analysis of the 2005/06 data gives similar results. Again, Lahore, Sheikhupura, and Faisalabad are highly significant and positive (Table 2), in line with the theory as they are heavily endowed with production labor. Sargodha, Gujrat, and Gujranwala are significant at the

\footnotetext{
${ }^{4}$ Gujrat and Sargodha are significant for both years, but Attock and Kasur are significant for 2000/01.
} 
10 percent level with a positive sign, given that they have abundant production labor. The ratio of both workers is also less than 1, giving the same result (Table 2).

Narowal and Rajanpur are the only two significant districts with a negative sign. These results are on the basis of only three observations (industries operating in the district). A negative sign would imply that, on average, the relative wage bill for nonproduction workers in these districts is lower than the relative wage bill for nonproduction workers in Punjab. Table 4 supports this result: 100 percent of manufacturing workers are employed in skill-intensive industries, leading to the conclusion that production labor is scarce.

However, on closer examination of the ratio of nonproduction to production workers for each district, we see that the number of production workers is relatively greater for Rajanpur. Two of the three industries present in these districts are common to both: grain milling and industries processing animal fat byproducts. In addition, Rajanpur has a sugar industry and Narowal manufactures engines and motors. Other than the latter, none of the other industries is very skill-intensive, which implies that these results are due mainly to the thinness of the formal manufacturing sector in these regions. It can also be argued that these industries are highly mechanized and require fewer production workers.

A comparison of 2000/01 and 2005/06 shows that, by and large, the coefficients that are statistically significant in both years are stable both in terms of size and sign. There is a minor increase in magnitude, moving from 2000/01 to 2005/06. Stable coefficients indicate low mobility of labor because labor movements from one region to another should eliminate factor price inequalities (workers move from places where their skill is in abundance and earns a relatively lower wage to districts where their skill is scarce and will receive a wage premium). However, highly stable and increasing coefficients clearly point to likely hindrances to labor mobility, which has led not only to FPE failure but also increased the wage gap between nonproduction and production workers in the period studied.

As Table 2 shows, there are some significant districts for which the significance and signs have changed. Among them, Rawalpindi is significant only for 2005/06. In the case of Rajanpur, the size, significance, and sign all change considerably over the period studied. This may be a result of very few observations for 2000/01. Table 1 shows that Rajanpur accounts for less than 0.1 percent of total manufacturing employment. Dera Ghazi Khan also has a highly variable coefficient: while the number of 
industries remains the same, the percentage share of total manufacturing employment falls from 2 to 0.8 percent.

Attock is also significant at 10 percent for 2000/01 but not for 2005/06 (Table 2). The reason for this could be a change in endowments as the ratio of nonproduction to production workers doubles over time from 0.2 to 0.4 (Table 5). This change suggests a relatively large number of nonproduction workers, which may have led to the removal of wage differences. Similarly, Rawalpindi is significant for 2005/06 but not for 2000/01 (Table 2).

We would normally expect large cities belonging to the industrial hub, such as Lahore, Faisalabad, Gujrat, and Sargodha, among others, to have a relatively high number of nonproduction workers, given there are more educational opportunities available here. The more plausible explanation is that, in these areas, nonproduction workers are engaged in other sectors, mainly in services. In most districts in central Punjab and mainly in the industrial hub, white-collar workers have numerous opportunities to work in other sectors, particularly the services sector, which currently makes up more than 50 percent of GDP and employs at least a third of the workforce (Ahmed \& Ahsan, 2011).

Nonproduction workers may be inclined to work in sectors other than manufacturing, resulting in the creation of an artificial shortage of nonproduction workers in this sector. Thus, the movement of nonproduction workers to the services sector might explain the relatively low number of nonproduction workers.

The results for Pakistan are similar to those obtained when testing for RFPE in Mexico by Bernard et al. (2010). They conclude that the uneven distribution of factors explains the relative factor price inequality. In the case of Pakistan, we trace this to lumpy factors of production. The extent of individual coefficient significance is slightly different. For Mexico, almost all the coefficients are significant, but for Pakistan fewer districts have a relative wage that is statistically different from the Punjab average. Thus, factors are somewhat more evenly distributed in Pakistan's case, which leads to less variation in factor prices.

The direction is different for Mexico, where nonproduction workers are the abundant factor. Production workers thus receive a wage premium and the coefficient signs are mostly negative. For Pakistan, however, the coefficient signs are positive because nonproduction workers are relatively scarce. There is also a difference in the size of coefficients: in 
Bernard et al. (2010), the coefficients are smaller and less than 1 on average; in our analysis, the coefficients are larger.

This could be due to the absence of rich data such as that of Mexico, where the number of industries present in each district is significantly higher and there is less variation in factors and industries across districts. In other words, the data for Pakistan features sharp variations in the number of industries and employment across regions. This lumpiness contributes to the higher difference in factor prices for Pakistan. The difference in magnitude is also an indicator of greater factor price inequality as there is more variation in prices between the districts and the base region.

There are few significant district dummies in our regressions. This may also be due to data problems. In some districts, there were too few industries for a coefficient to be estimated. Narowal and Vehari were dropped from the regression for 2000/01 because only two and three industries, respectively, operate in these districts and there were not enough observations to include in the regression. Similarly, only three industries were operating in Layyah in 2005/06, yielding too few observations to retain it. Finally, Nankana Sahib is absent in the 2000/01 regression because it was not a separate district in the CMI for 2000/01.

\subsection{Mincerian Wage Regression Test}

The methodology developed by Bernard et al. (2010) is used to estimate differences in worker quality, given that variations in this can affect relative wages. We test for the relationship between relative endowments and wages after accounting for observable differences in worker quality. The intuition behind this is to eliminate the effect of worker quality on wage differences and determine if the endowment of factors explains the variation in factor prices.

As explained in Section 4, the variation in prices could simply be due to variations in worker quality. After adjusting for worker quality, we expect to find an inverse relationship between quantity (relative endowment) and wages. Thus, in areas that are heavily endowed with production workers, nonproduction workers will have the benefit of a wage premium.

The PSLMS for 2008/09 is used for this analysis and a Mincerian wage equation is calculated for every district. Since the survey does not report the industry to which an individual belongs, we restrict our analysis to the district level. In the absence of any measure of work experience, we 
use age as a proxy. ${ }^{5}$ After running the Mincerian wage regressions, the coefficient for the quality-adjusted wage for every district is calculated by taking the constant term from the regressions for every district.

The ratio $\frac{\alpha_{i j}{ }^{n}}{\alpha_{i j}{ }^{p}}$ is calculated by dividing the alphas for both types of workers for every district. This gives the relative wage independent of the effect of observed characteristics (worker quality). To calculate the worker quality-adjusted workforce, we compute the estimated wage from equation (2) (see previous section) for every district and type of worker. The estimated wage is then divided by alpha to remove any impact of worker quality. Summing $\frac{w^{\prime}}{\alpha}$ for production and nonproduction workers for every district gives us an estimate for the number of quality-adjusted production and nonproduction workers in each district.

Table 5 gives estimates for both $\frac{\alpha_{\mathrm{ij}} \mathrm{n}}{\alpha_{\mathrm{ij}} \mathrm{p}}$ and $\frac{\mathrm{w}^{\prime}}{\alpha}$ for all 35 districts. The coefficient in the regression of the quality-adjusted wage on the qualityadjusted relative quantities of nonproduction and production labor is 0.034 and statistically insignificant. As we have only 35 districts, we also take the correlation coefficient of both series, which is 0.0608 . This low value implies that there is a weak relationship between the wage ratio (the relative wage of nonproduction to production workers) and the quantity ratio (the relative endowment of nonproduction to production workers).

The results indicate that the relative wage ratio positively affects the quantity ratio, but nothing more concrete can be concluded because the coefficient is insignificant. This contravenes our expectations: according to the literature, there should be a negative relationship between the qualityadjusted wage quantity ratio and the quality-adjusted wage when factors are lumpy. For instance, a relatively large number of nonproduction workers operating in a region will experience a relatively lower wage in comparison with production workers.

The argument is identical to the HOS theorem that the relatively abundant factor will experience lower returns. Bernard et al. (2010) carried out a similar analysis to examine reasons for the lack of relative factor price inequality. In other words, can the absence of RFPE be explained by the presence of a lumpy factor distribution? The deviations from RFPE are less severe for Pakistan than for Mexico and so the absence of a significant

${ }^{5}$ A reviewer has suggested using the latest PSLMS, which provides information on experience. However, given that the first part of the study uses the CMI for 2005/06, we feel that the wage data from the PSLMS for 2008/09 is closer to that for 2005/06 and is, therefore, the better choice. 
inverse relationship between wage ratios and wage quantity is not unjustified. However, our analysis is not as precise as Bernard et al. (2010) since the PSLMS does not provide information about the industry in which workers are employed and, therefore, the analysis is restricted to the district level (rather than the industry level).

Table 5: Adjusting for worker quality

\begin{tabular}{|c|c|c|}
\hline District & $\alpha^{n} / \alpha^{p}$ & W/ $\alpha$ \\
\hline Sahiwal & 1.000 & 0.246 \\
\hline Chakwal & 1.404 & 0.280 \\
\hline Narowal & 2.180 & 0.305 \\
\hline Sialkot & 1.415 & 0.351 \\
\hline Gujrat & 0.647 & 0.356 \\
\hline Gujranwala & 0.549 & 0.402 \\
\hline Nankana Sahib & 2.024 & 0.426 \\
\hline Hafizabad & 1.116 & 0.428 \\
\hline Mandi Bahauddin & 0.350 & 0.451 \\
\hline Vehari & 1.204 & 0.452 \\
\hline Bhakkar & 0.742 & 0.492 \\
\hline Bahawalpur & 0.350 & 0.500 \\
\hline Attock & 0.680 & 0.537 \\
\hline Okara & 0.379 & 0.596 \\
\hline Khushab & 0.714 & 0.633 \\
\hline Rawalpindi & 0.916 & 0.641 \\
\hline Sheikhupura & 1.107 & 0.696 \\
\hline Muzaffargarh & 0.513 & 0.737 \\
\hline Kasur & 0.853 & 0.799 \\
\hline Jhelum & 0.679 & 0.816 \\
\hline Pakpattan & 0.346 & 0.821 \\
\hline Mianwali & 0.759 & 0.903 \\
\hline Faisalabad & 0.535 & 0.963 \\
\hline Khanewal & 0.631 & 1.114 \\
\hline Jhang & 0.449 & 1.173 \\
\hline Multan & 0.612 & 1.202 \\
\hline Sargodha & 0.442 & 1.328 \\
\hline Toba Tek Singh & 0.378 & 1.341 \\
\hline Lahore & 0.748 & 1.506 \\
\hline Bahawalnagar & 0.900 & 1.564 \\
\hline Lodhran & 0.932 & 1.791 \\
\hline Rajanpur & 1.045 & 1.858 \\
\hline Rahimyar Khan & 0.870 & 2.166 \\
\hline Dera Ghazi Khan & 1.203 & 3.147 \\
\hline Layyah & 1.444 & 3.788 \\
\hline
\end{tabular}

Source: Author's calculations 
A closer look at Table 5 illustrates the point established in the previous analysis: on average, Pakistan has abundant production workers. The data in Table 5 is organized by increasing values of the qualityadjusted worker ratio of nonproduction to production workers. Clearly, in most regions, nonproduction workers are relatively scarce. We can also compare our earlier results (where quality adjustments had not been made) to the numbers here. This reveals some interesting points.

First, the signs of almost all the statistically significant coefficients from the earlier FPE regressions (Table 2) are justified. For districts situated in the industrial hub, such as Gujrat, Gujranwala, Faisalabad, and Sheikhupura, the value of quality-adjusted workers is less than 1, which indicates that, after adjusting for worker quality, the number of production workers is still greater than nonproduction workers. Only for Lahore and Sargodha is the ratio greater than 1 , which implies that they have a larger number of nonproduction workers (in contrast to the results in Table 2).

Second, after adjusting for quality, relative endowments have risen. ${ }^{6}$ This is because most of the values in Table 3 are lower than 0.5 , while the Table 5 gives higher values. This is important because the counterintuitive result we obtained for the industrial hub in the previous section does not hold firmly for this analysis. Although the values are still less than 1, the relatively higher values indicate that, after adjusting for worker quality, nonproduction workers are relatively large in number.

It may be either that, if we account for differences in worker quality, the number of production workers has effectively fallen or that the effective number of nonproduction workers has risen. It is very difficult to establish a clear relationship between factor endowments and their returns, but the earlier results on the scarcity of white-collar worker are confirmed. There may also be a persistently uneven distribution of factors across districts, even after controlling for worker quality differences.

\section{Conclusion}

This paper has examined RFPE across the districts of Punjab. We find that wages differ significantly across the province, given that all the district dummies are jointly significant. The individual coefficients tend to be significant in districts with a large number of industries. The size of almost all coefficients is found to be positive, which means that the relative wage bill of a nonproduction worker in a district is higher than that of a nonproduction

\footnotetext{
${ }^{6}$ Endowments for the previous analysis are given in Table 3 and also shown in the form of a graph.
} 
worker in the rest of Punjab. These results are in line with the HOS theorem: as the scarce factor, nonproduction labor enjoys a wage premium.

We have established the presence of factor price inequality from the data, but not to the extent suggested by studies conducted for other countries using the same methodology. This can be attributed to data shortcomings or to the argument that, in Pakistan, there is less variation in factor prices compared to other countries. There is also no correlation between factor endowment and return because there is no inverse relationship between the quantity ratio and wage ratio, even after adjusting for observed quality.

Another interesting pattern observed is the presence of more bluecollar workers in relatively better developed areas in central Punjab, where the ratio of nonproduction to production workers representing the districtwise endowment is less than 1. This is different from our expectations and shows that, even in relatively developed areas of the province, nonproduction workers are scarce in the manufacturing sector. 


\section{References}

Ahmed, A., \& Ahsan, H. (2011). Contribution of services sector in the economy of Pakistan (Working Paper No. 2011: 79). Islamabad: Pakistan Institute of Development Economics.

Berger, H., \& Westermann, F. (2001). Factor price equalization? The cointegration approach revisited. Review of World Economics, 137(3), $525-536$.

Bernard, A. B., Redding, S. J., \& Schott, P. K. (2009). Testing for factor price equality in the presence of unobserved factor quality differences. Unpublished manuscript. Retrieved from (http://www.princeton. edu/ reddings/papers/usfpe_038.pdf).

Bernard, A. B., Redding, S. J., Schott, P. K., \& Simpson, H. (2002). Factor price equalization in the UK? (Working Paper No. 9052). Cambridge, MA: National Bureau of Economic Research.

Bernard, A. B., Robertson, R., \& Schott, P. K. (2010). Is Mexico a lumpy country? Review of International Economics, 18(5), 937-950.

Burgman, T. A., \& Geppert, J. M. (1993). Factor price equalization: A cointegration approach. Review of World Economics, 129(3), 472-487.

Courant, P. N., \& Deardorff, A. V. (1992) International trade with lumpy countries. Journal of Political Economy, 100(1), 198-210.

Cunat, A. (2001). Can international trade equalize factor prices? Unpublished manuscript, London School of Economics, UK.

Davis, D. R., \& Weinstein, D. (2001). An account of global factor trade. American Economic Review, 91(5), 1423-1453.

Deardorff, A. V. (1994). The possibility of factor price equalization, revisited. Journal of International Economics, 36(1-2), 167-175.

Debaere, P. (2004). Does lumpiness matter in an open economy? Studying international economics with regional data. Journal of International Economics, 64(2), 485-501.

Debaere, P., \& Demiroglu, U. (2003). On the similarity of country endowments. Journal of International Economics, 59(1), 101-136. 
Dixit, A., \& Norman, V. D. (1980). Theory of international trade: A dual, general equilibrium approach. Cambridge: Cambridge University Press.

Hanson, G. H., \& Slaughter, M. J. (2002). Labor-market adjustment in open economies: Evidence from US states. Journal of International Economics, 57(1), 3-29.

Leontief, W. (1953). Domestic production and foreign trade: The American capital position reexamined. Proceedings of the American Philosophical Society, 97(4), 332-349.

Mincer, J. (1958). Investment in human capital and personal income distribution. Journal of Political Economy, 66(4), 281-302.

Repetto, A., \& Ventura, J. (1997). The Leontief-Trefler hypothesis and factor price insensitivity (Working Paper No. 97-13). Cambridge, MA: MIT.

Samuelson, P. (1948). International trade and the equalization of factor prices. The Economic Journal, 58(230), 163-184.

Tomiura, E. (2005). Factor price equalization in Japanese regions. Japanese Economic Review, 56(4), 441-456.

Trefler, D. (1993). International factor price differences: Leontief was right. Journal of Political Economy, 101(6), 961-987. 